\title{
Introduction
}

Revolutions are a resolute and conscious

attempt ... to break with the past

-Alexis de Tocqueville $\mathrm{n}$ the early twentieth century, Sigmund Freud and Carl Jung devel-
oped two distinct theories of psychoanalysis based on their differing conceptions of the unconscious mind. Their schools of psychoanalysis remain active today, although they have witnessed substantial modifications. As secular psychological approaches, neither is based directly on religious tradition. Freud specifically rejected any link between psychoanalysis and religion, whereas Jung viewed his mode of analytical psychology as within the tradition of ancient religious healing practices.

The history of ideas includes an examination of conceptual borrowings. Secular thought did not spring de novo from the enlightened mind; instead, it emerged out of two millennia of religious tradition in the West. It would be naive to presume that this lengthy heritage has not contributed to how modern minds see the world. This is particularly evident in the field of psychology, where values and modes of thought can be traced back to once-prevalent religious ideas.

The discovery of the unconscious (Ellenberger 1970) has in fact been a process, not an event. It has been nothing less than the slow unfolding of ideas, some of which have gained the light of day only to sink back again into a barely perceptible darkness. As will be discussed below, the Judeo-Christian ethic continues to inform our modern conceptions, and often without our awareness. This extends to the 
modes of psychoanalysis developed by Freud and Jung, whose debt to religious ideas has never been fully acknowledged.

Scholars have referred to the partitioning of Judaism and Christianity as the "parting of the ways" (Boyarin 2006). This was a process that took place over centuries, and was determined by mutual positive and negative influences, which tended to polarize the positions of the rival religions. It will be demonstrated here that a comparable process has sculpted, and in many respects also distorted, the positions taken by Freud and Jung. Following their final rift in 1912, Freud's writings were for a brief time aimed at refuting Jung's unorthodox ideas concerning the psyche. Jung, in turn, continued to take exception to Freud's notions concerning the unconscious, and he abandoned the domain of personal psychology in order to focus on the collective features of the psyche. While there are indications that each man kept abreast of the other's work, in their later years they rarely referred to each other. This has been the legacy for their intellectual heirs, as well. Unfortunately, such purposeful neglect has tended to limit the scope of their respective approaches.

\section{PSYCHOANALYSIS AND THE ENLIGHTENMENT}

Secular thought tends to obscure dependence on religious ideas by clothing them in the language of scientific empiricism. In order to discern the religious motifs that inform secular thought, this veil must be penetrated. Claims that new ideas arise de novo must be dismissed as incorrect, as they emerge necessarily from older ones, and continue to carry the latter's indelible impressions. According to the philosopher Amos Funkenstein:

The "new" often consists not in the invention of categories or figures of thought, but rather in a surprising employment of existing ones. Of the variety of ways in which a new theory can be said to have been prepared by an older one, two ideal modes are particularly pertinent ... the dialectical anticipation of a new theory by an older, even adverse one . . . and the transplantation of existing categories to a new domain. (Funkenstein 1986, 14) 
This conclusion applies also to the debt that psychoanalysis owes religion. But identifying the religious underpinnings of psychoanalysis is complicated by a paucity of direct acknowledgements of the latter's borrowings, especially in Freud's writings, which convey a distinctly negative attitude towards religion. However, as will be demonstrated, this belies Freud's reliance on religious ideas, so that one must look carefully past Freud's manifest narratives in order to identify the latent motifs of religion. For Freud, religion, and specifically Judaism, is the unconscious element that must be defended against, yet manifests in much of his thought.

\section{CURE OF THE SOUL}

Until relatively recent times, religious practice was the dominant mode of countering psychological disturbances. The religious "cure of the soul" was the dominant mode of psychotherapy. Carl Jung acknowledged the therapeutic role of religion as follows:

What are religions? Religions are psychotherapeutic systems. What are we doing, we psychotherapists? We are trying to heal the suffering of the human mind, of the human psyche or the human soul, and religions deal with the same problem. Therefore, our Lord is a healer; he is a doctor. He heals the sick and he deals with the trouble of the soul, and that is exactly what we call psychotherapy. (Collected Works, vol. 18, para. 181)

In his Eight Chapters (Pirke Shemoneb) the twelfth-century Jewish scholar and physician Maimonides (R. Moshe ben Maimon) (Figure 1) outlines how psychologically troubled individuals should be approached, offering prescriptions that read like modern cognitive-behavioral therapy (Bakan et al. 2009). Maimonides opines, like Aristotle, that actions are virtuous when they achieve a "middle path" between extremes. Accordingly, an individual who has become mentally unsound is encouraged to practice the extreme opposite of his undesirable behavior until the fault had been remedied. For example, if a man 


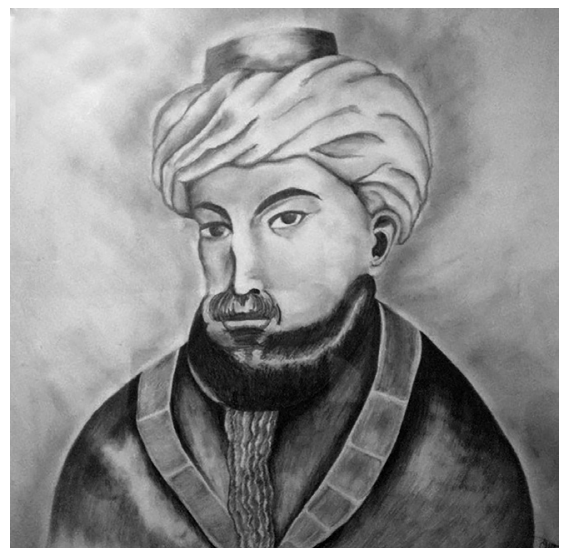

Figure 1. Moses ben Maimon or Maimonides was a twelfth-century rabbinic scholar and Jewish philosopher who compiled the Mishneh Torah and authored Guide of the Perplexed. His standing as a sage is essentially unrivaled.

is a miser, he is encouraged to spend extravagantly until his niggardliness has been extinguished. Only then can he be persuaded to be generous in moderation. Maimonides' approach is active, directive, symptom-based, and highlights the importance of behavioral change in the cure of the soul.

\section{RELIGION AND PSYCHOANALYSIS}

Other scholars have previously examined the influence of religion on psychoanalysis. During Freud's own lifetime, A. A. Roback argued that psychoanalysis was peculiar to the make-up of the Jewish mind (1929), a suggestion that Freud rejected. ${ }^{1}$ The historian David Bakan opined that mystical Judaism had played a role in the development of psychoanalysis and that Freud had been a crypto-Sabbatean, i.e., a member of a messianic sect that secretly followed the banned teachings of Sabbatai Tzvi, although this claim has been rejected by most scholars (Bakan et al. 2009). The psychoanalyst Ana-Maria Rizzuto addressed Freud's ambivalent relationship to God, arguing that unresolved Oedipal issues with his father's Judaism were the primary cause of Freud's atheism (1998).

1. For detailed readings on this topic, see Lew Aron and Karen Starr, A Psychotherapy for the People (London: Routledge, 2013) and Stephen Frosch, Hate and the Jewish Science (London: Palgrave MacMillan, 2009). 
The psychologist Sanford Drob has examined the role of the Kabbalah in both Freudian and Jungian analysis (2000), and more recently Karen Starr (2008) and Michael Eigen (2012) have addressed parallels between mystical Judaism and psychoanalysis. Many of these ideas are revisited in the present text. Whereas several neo-Freudian psychoanalysts, including Steven Frosh (2009) and Lew Aron and Karen Starr (2013), agree that Freud's Judaism influenced the directions of his thought, they are wary about labeling psychoanalysis a "Jewish science," as they are justifiably concerned that this might fuel anti-Semitic prejudice. Others have addressed the influence of Christianity on Jung's ideas, and in this regard the works of the Jungian analysts Edward Edinger (1976) and Murray Stein (2012) are noteworthy.

The present text demonstrates that the religious underpinnings of psychoanalysis are both more specific and extensive than have been previously entertained, and that the distinct tenets and practices of traditional Judaism and Christianity account in large measure for the differences that emerged respectively in the theories and practices of Freud and Jung.

\section{RELIGION AND PSYCHOLOGY}

Jung, a onetime disciple and colleague of Freud, ${ }^{2}$ suggested that all aspects of human experience, including religious ones, are "psychological," and should be considered as such: "Everything to do with religion, everything it is and asserts, touches the human soul so closely that psychology least of all can afford to overlook it" (CW 11, para. 172). Jung's notion that religion is psychological raises few objections; however, the converse invariably raises many. This in part results from Freud's having viewed religion as steeped in superstition and

2. Many modern Jungian analysts take issue with the idea of Jung as a disciple of Freud's. They claim that Jung was already an established psychiatrist with his own theories concerning the psyche before encountering Freud. I do not tend to agree with this assessment, and it share similarities with the discomfort that early Christians had with the idea of Jesus being baptized by John the Baptist. As the Jesuit priest and scholar J. P. Meir argues in his magisterial opus A Marginal Jew (1991), stories in the New Testament that run counter to the dogma of the church likely reflect actual historical situations. In the same vein, there can be little doubt that Jung was a disciple of Freud's and espoused his doctrines at least for a limited time. 
metaphysics, whereas psychoanalysis was, in his opinion, necessarily scientific and devoid of metaphysical underpinnings. Jung's stance on religion, to the contrary, was generally benevolent, and he agreed that religious ideas informed psychoanalysis. But neither man chose to address how their own religious beliefs influenced their theories of psychoanalysis, and this is the aim of the present text.

Whereas the Judeo-Christian ethic has contributed to modern psychotherapeutic thought, it must be acknowledged that Judaism and Christianity are complete soteriologies in their own right, ${ }^{3}$ and they continue to compete with psychotherapy. There are large numbers of devotees of each tradition, who, as a result of the salutary effects of confession and ritual expurgation, rarely seek the assistance of a psychotherapist. ${ }^{4}$ For them, religion is by itself a source of healing. Indeed, it may be argued that religions, when optimally practiced, may offer more opportunities for psychological healing than do modern secularized modes of psychotherapy, for reasons that will be addressed.

\section{HEALING AND RELIGION}

Healing is a rubric for a set of innate processes that antagonize the signs and symptoms of "dys-ease." The concept of healing remains ambiguous, in part, because it derives from a pre-scientific era when body and soul were still experienced as interdependent and interpenetrating. Whereas healing can be fostered by drugs, surgeries, and psychological interventions, it cannot succeed without the innate activities of the body.

Healing occurs beyond consciousness (Kradin 2011); one cannot consciously will oneself to be well. For those who profess deep religious beliefs, healing is attributed to divine intervention, whereas for the secular individual, it is credited to biological processes. However, these ideas are not necessarily mutually exclusive, as many modern theologians

3. One of the most detailed religious psychologies can be found in Theravada Buddhism, although it does not adhere to the notion of a soul. Nevertheless, it clearly has therapeutic and soteriological aims.

4. One can arrive at the same conclusion for any of the major religious systems, all of which offer modes of psychological healing together with the larger goal of salvation. 
would agree that God acts through the natural laws of creation (Sacks 2011). Indeed, prominent scientists (e.g., Newton and Einstein), have historically held strong metaphysical beliefs. Nevertheless, a modern-day atheist and God-fearing religionist would likely disagree on this issue based on their distinct weltanschauungs. ${ }^{5}$

Healing must be distinguished from curing. "To heal," from the Old English baelen, means to restore to health or "to make whole." Health may be defined as a state of psychophysical well-being, in which mind and body are experienced as working harmoniously together (Kradin 2004). But words do not adequately convey the experience of wholeness. "Cure" is derived from the Latin curare, which means "to take care of." A second meaning refers to the treatment of flesh in order to remove undesirable elements, as, for example, in the "curing" of beef. In medical parlance, it is the latter that is most often implied, as it is possible to be "cured" of a disease yet remain in poor health.

In the realm of mental pathology and healing, it may be too optimistic to speak of health. Patients suffering from psychological ills may be cured of their symptoms (e.g., depression), without achieving enduring mental health. Indeed extensive arguments have been raised over the years as to whether symptomatic and goal-oriented cures may have advantages over efforts at reconstructing the psyche towards a state of ill-defined health. ${ }^{6}$

The history of healing is too extensive to rehearse here. As Guido Majno addresses in Healing and Disease (1975), homo medicamentosa is also bomo religiosus, and virtually all religions include approaches to the diagnosis and treatment of disease (Eliade 1964). While it is easy with hindsight to dismiss ancient treatments as naive, there is little doubt that pre-scientific modes of therapy were often effective for reasons that modern science cannot explain. Historical perspective also dictates

5. Joseph Ratzinger, the former Pope Benedict XVI, in his Introduction to Christianity, makes the interesting argument that both religionists and atheists show an unusual interest in religion, pointing to how most atheists are not in the least impartial with respects to their strongly held antithetical beliefs in a God, and that "the Lady doth protest too much."

6. This controversy is reviewed by Aron and Starr, and the reader is encouraged to evaluate their arguments (2013). 
that the currently accepted scientific approaches to disease will in some instances be in the future also be viewed as outmoded and naive.

Modern placebo-controlled clinical trials have repeatedly demonstrated that rational approaches to disease are by no means a guarantee of efficacy, whereas approaches that appear irrational can yield salutary outcomes (Kradin 2011). As the medical anthropologist Craig Moerman has suggested, the healing process includes mental structures of meaning that do not necessarily follow rational ideas (2002).

\section{JUDAISM AND HEALING}

Judaism is an ancient religious tradition that addresses ailments that afflict both mind and body (Biale 2002). The Torah (the Five Books of Moses, or Pentateuch) is the textual foundation of Judaism; however, healing plays a relatively minor role in its narratives. The Torah includes a single brief prayer by Moses in Numbers 12:13, which petitions YHWH to heal his sister Miriam of tzaraat. "Please God, heal her." This disorder, invariably mistranslated as "leprosy," in fact resembles no disease known to modern medicine, as it also "afflicts" articles of clothing and the walls of houses. Tzaraat was attributed to the sin of having spoken ill of others (lashon ha ra). It appears that the single example of healing in the Torah pertains to a metaphysical disorder.

Later rabbinic commentaries include numerous references to actual physical (guf) and mental (nefesh) disorders, and the modern Jewish liturgy is replete with supplications for healing. As a monotheistic religion, Judaism attributes disease and healing to divine intervention, and it was only in the apocryphal Wisdom of Ben Sirah (Skehan and DiLella 1995), authored in the third century BCE, that the beneficial role of the physician was first given credence. ${ }^{7}$

7. The Wisdom of Ben Sirach is frequently cited in the Talmud. It was originally authored in Hebrew and translated by the author's grandson into Greek. While apocryphal to the Masoretic text of the Hebrew Bible, it is included within the Greek Septuagint. 
In the Hebrew Bible, the cause of disease was judged to be either sin (moral impurity), or ritual impurity left unattended (Klawans 2004). The most common Hebrew word for sin, cheyt, is an archery term that means "to miss the mark" - that is, a failure to observe the Law properly. Observance of the Mosaic Law with its 613 precepts-248 positive ${ }^{8}$ and 365 negative-is the cardinal tenet of Rabbinic Judaism, and even rote observance of these precepts fulfills one's legal religious obligations, although concomitant proper intentionality in is considered optimal.

However, few individuals can consistently achieve righteous discipline in their observance, and as the intentions of others cannot be evaluated, objective action has traditionally been prioritized in Judaism, so that it is commonly viewed as a system of orthopraxy (right action) rather than orthodoxy (right belief). But the motivation to observe the Law is meritorious, as obligations, if approached with proper intention, offer frequent opportunities to sacralize the mundane world. ${ }^{9}$ When practiced with the right attitude, rather than constituting a burden, the observance of Jewish Law can imbue meaning to personal, family, and community life. But if the Law is observed merely by rote, its rituals begin to resemble an obsessional neurosis, as Freud noted (Freud 1907).

Proverbs 9:10 states that, "The beginning of wisdom is fear of God." The Law with its commandments and proscriptions conjures notions of responsibility, culpability and punishment. While fear of God is viewed by some as an unduly harsh concept and one that is irreconcilable with a loving God, acceptance of the awesome effects of divine action is a cardinal tenet of Judaism. This is famously addressed in the dialogical arguments of the Book of Job concerning theodicy (Kradin 2014).

8. The 248 positive commandments correspond with the 248 "members" of the body. This emphasizes the requirement of the body in performing these positive commandments.

9. This text is largely based on this critical difference between Judaism and Christianity. Once again, without being properly and deeply understood, the Law quickly becomes burdensome, as it did for the early Christians and others throughout the history of Judaism. 


\section{SIN AND DISEASE}

Evil is a poorly defined term that is linked conceptually with sin. One explanation within the Judeo-Christian tradition for how evil first entered the world is via Adam's original sin. Man's failure to obey the divine injunction of not eating from the Tree of Good and Bad was the first example of his failure to fear God. ${ }^{10}$ The punishment for this disobedience included work, the pain of childbirth, and awareness of one's eventual death.

In the fourth century, the church father Augustine introduced the notion of original sin as the inherited predilection of Adam's descendants to disobey divine will. Man is born tainted by sin, according to Augustine, and lacks wholeness. But according to rabbinic interpretation, sin is not inherited, despite certain references in the Torah that suggest otherwise (e.g., Exodus 20:6), but rather attributable to man's hedonistic psychological inclination, the yetzer, which Freud later re-imagined as a pleasure-seeking drive in the unconscious (Rotenberg 1997). The rabbis in late antiquity postulated opposing mental impulses: one, the yetzer ha tov, or good impulse, attuned to the proper fulfillment of divine will; the other, the yetzer ha ra, or bad impulse, which seeks personal satisfaction in opposition to it. The rabbis had in fact developed a psychodynamic system, one based on contradictory impulses, and comparable to Freud's modern notion of mental conflict.

The idea of competing metaphysical forces of good and evil likely entered Jewish thought via Zoroastrianism during the Babylonian Exile of the late sixth century BCE. Adherence to a belief in radical duality has been identified by scholars within the writings of certain sects of Second Temple Judaisms. One of these sects, Christianity, viewed sin as having its origins as a metaphysical force that eternally opposes the will of God (Pagels 1995). The Gospel authors imagined Satan as the

10. Christianity takes a relatively negative view of this act and Augustine refers to it as the source of the original sin that was transmitted to all subsequent generations. Rabbinic Judaism is more ambivalent concerning the infraction. At one level, it is viewed as the first sinful behavior, on the other, its effects are recognized to have contributed to man's proper place in the world vis-à-vis knowledge and choice. 
serpent in the Garden, who tempted Eve to transgress God's command not to eat of the fruit of the Tree of Knowledge but failed to lure Jesus to sin while in the desert immediately following his baptism. Psychologically speaking, Satan acts effectively by introducing doubt; the Devil (from the Sanskrit $d v a$ meaning "double" or "dishonest") undermines man's undivided faith in God.

Ha Satan first appears in the canonical Job, where he is portrayed as a prosecutorial angel, who questions God's judgment but is obedient to God's will. Rabbinic Judaism eschewed radical duality as it undermines the ideal integrity of monotheism. The second-century rabbis were heirs to a fiercely monotheistic Deuteronomic tradition, which envisioned an unchallenged God who was responsible for all of creation, including what man might interpret from his limited perspective as a good and evil. As the Jewish prophet Isaiah (45:7) states in the name of YHWH, "I form the light, and create darkness: I do the good, and the bad; I, YWHW, do all these things."

Yet the rabbis also embraced the idea that man was invested with free will and ultimately responsible for his choices. This idea was expressed by R. Akiva in the Ethics of the Fathers (Pirke Avot) 3:15, writing that, "All is fated, but free will is given." This idea shares features with modern deterministic chaos theory, which has been used to mathematically model complex systems, including the mind (Eigen 2013). According to chaos theory, the broad outlines of mental activity are determined, comparable to fate, yet sensitive to minor perturbations, analogous to individual choice.

The ancient Israelite religion addressed sin in a highly ritualized manner. Healing required first recognizing one's sin, confessing it to a priest, expressing genuine repentance (t'shuva)-which means returning to God-and then bringing an expiatory sacrifice to the Temple. As Maimonides notes in his Mishneb Torah, since the destruction of the Temple, confession and repentance have replaced sacrificial offerings (1990).

11. The acronym YHWH is referred to as the Tetragammaton and represents the ineffable name of God, which may be either unpointed or pointed as the word Adonai, which means "my Lord." 
In the ancient Israelite sacrificial ritual, one discerns a parallel with the Freudian idea of "working through," in which initial cognitive awareness of motive deepens with time, until genuine change is realized. An ancient Israelite who believed that he had committed a transgression of the Law "in error" (shogeg), was required to bring a guilt offering in order to repent. But if upon further introspection, he recognized that what he had initially thought to be due to error had in fact been motivated by desire, then bringing a second appropriate sin offering was necessary.

The logistical confluence of the confessed sinner, the priest, the sacrifice, and God was required if the ritual was to be efficacious. During the sacrifice, man and God were imagined as drawn together in at-one-ment. One can only speculate as to whether modern psychological modes of expiation are as effective as the dramatic act of sacrificing the life of an animal in order to be cleansed of sin.

But after the Second Temple was destroyed, it was no longer possible to atone for sin through sacrifice, and alternative approaches were necessary (Neusner 1978). These had already developed following the destruction of the First Temple in 586 BCE, and while the Jews were in exile in Babylonia. There is a passage in an early biblical commentary, in which R. Yochanan ben Zakkai, who is credited with having instituted the earliest practices of Rabbinic Judaism in $70 \mathrm{CE}$, was asked by a student how sin would be forgiven in the absence of the Temple:

Once as Rabbi Yochanan Ben Zakkai was coming forth from Jerusalem, Rabbi Joshua followed him and beheld the Temple in ruins. "Woe unto us," Rabbi Joshua cried, "that this place where the iniquities of Israel were atoned for is laid to waste!" "My son," Rabbi Yochanan said to him, "be not grieved. We have atonement as effective as this. And what is it? It is acts of loving-kindness, as it is said, 'For I desire mercy and not sacrifice.' [Hosea 6:6]" Avot de Rabbi Nathan, chapter 6 (quoted in Goldin 1990, 34) 
Centuries before the destruction of First Temple, the ancient Israelite prophets had warned that the sacrificial penitential ritual had become rote and insincere. The prophets argued that God wanted sinners to raise their ethical standards by showing appropriate concern for the oppressed within society, traditionally the widow, the orphan, and the stranger, who were rarely able to support themselves. The rabbis looked to the prophetic ideas that charity, the performance of good deeds, and prayer were of greater importance than animal sacrifice. In a novel mode of accounting, the rabbis suggested that deeds of "loving-kindness" could be weighed in the balance against previous sins. The penitent sinner was virtually assured of forgiveness and redemption. As Maimonides notes:

\begin{abstract}
T'shuva atones for all sins. Even a person who was wicked his whole life and repented in his final moments will not be reminded of any aspect of his wickedness as [Ezekiel 33:12] states "The wickedness of the evil one will not cause him to stumble on the day he repents his wickedness." (Mishneb Torah, halacha 3)
\end{abstract}

But T'shuva, as Maimonides defines it, is not a simple process. It requires the in-depth purging of sin, both mentally and behaviorally, in order to be effective. One must forego the impulse to sin again, not in the abstract, but when faced with identical enticements. The penitential system of Judaism insists on genuine transformation, which includes verifiable behavioral change.

\title{
MAGICO-THEURGIC HEALING
}

Apotropaic (i.e., the use of symbols and rituals to ward off evil) and theurgic practices were popularly practiced in parallel to the sacrificial cult by the ancient Israelites. This is evident from the polemics of the biblical prophets who repeatedly exhorted the Israelites to desist from adopting the practices of neighboring nations, including soothsaying, necromancy, divination, etc. The practices of the Canaanite cults of 
Asherah and Astarte were widely held to be effective in warding off maternal and fetal deaths during childbirth, and in warding off childhood illnesses (Kaufmann 1972).

It is difficult to differentiate religious from magical healing, as one man's religion may be another man's magic, and for this reason scholars prefer the term "magico-theurgic" healing. Although both appeal to supramundane forces, prayers are supplications, whereas magic endeavors to manipulate divine powers through spells, incantations, and rituals. ${ }^{12}$ Perhaps most widely recognized are the miraculous healings and exorcisms attributed to Jesus within the New Testament Gospels (Kradin 2010). The biblical scholar Morton Smith suggested that Jesus was in fact a first-century magician (Smith 1981), and he cites examples of comparable feats in the pagan Greco-Roman world, notably those credited to Apollonius of Tyana, whose story closely parallels Jesus'. Confusion between healers with claims to divine powers and magicians was a common trope in the ancient world. In modern times, charisma has also been attributed to the healing powers of the psychoanalyst, in the form of "transference cures" (Kakar 1991).

\section{HEALING AND THE SCIENTIFIC REVOLUTION}

From antiquity and through the Middle Ages, Jews and Christians were immersed in a pervasive milieu of religious belief, and the idea of a secular world with limited religious observance-what we today refer to as religion-was unknown. In his treatise, A Secular Age, the philosopher Charles Taylor opines that a progressive "disenchantment" of the world has occurred over the last five centuries (2007). Medieval man, according to Taylor, was permeable to metaphysical forces (e.g.,

12. In a curious side note, a recent study by H. Benson and colleagues, "Study of the Therapeutic Effects of Intercessory Prayer (STEP) in Cardiac Bypass Patients: A Multicenter Randomized Trial of Uncertainty and Certainty of Receiving Intercessory Prayer," American Heart Journal 151 (2006): 934-42, showed that patients with cardiac diseases who were told that they were being prayed for actually had worse outcomes than those who were not. The reason for this is uncertain but may reflect the so-called nocebo response, in which individuals actually do worse when given what would a priori be expected to have either a positive or neutral response. I explore reasons for this in my text, The Placebo Response: The Power of Unconscious Healing (London: Routledge, 2008). 
angels and demons), and the concept of the individual as independent of the spirit realm was unknown (Taylor 1989). The social historian Brad Gregory argues that secularism and science were unexpected by-products of the European Reformation, and that today only a dim awareness remains that man's perception of the world is still swayed by dimly perceived metaphysical notions (2012).

By the seventeenth century, the Enlightenment had infused the European mind with new heady possibilities of objectivity and intellectual freedom (Berlin 2013). For the first time, man was capable of imagining himself as no longer subject to divine whim, nor as a passive object buffeted by forces beyond his control; instead, he was now an active observer and participant within a world ruled by physical laws that could be expressed in mathematical terms and with predictable results. Man was now able to ponder the possibility of controlling his fate and environment without preconceived divine limitations.

The philosopher René Descartes posited that human cognition allowed one to separate oneself from nature for the purpose of observing it dispassionately (1988). This idea was instrumental in the decline of theological explanations and in the ascent of empirical observation. As the cosmos was disenchanted, God's role in creation also became increasingly difficult to define, and man's belief in mystery waned.

The Jewish philosopher Baruch Spinoza, in the seventeenth century, declared that God and his creation were in fact isomorphic (i.e., superimposable), which is the definition of pantheism (Garrett 1996). Spinoza did not deny God's existence, but neither did he recognize him as the creator. Instead, Spinoza saw God as present in all of creation but not outside of it. Like Maimonides, Spinoza opined that the highest form of religious achievement could only be attained through pure reason, but his ideas led to his excommunication. ${ }^{13}$

13. The State of Israel publically reclaimed Spinoza as the first secular Jew. However, it is not at all clear from his behavior in life that he would have welcomed being reinstated into the Jewish fold. His stance clearly was a rebuke of organized religion. D. Schwartz, The First Modern Jew: Spinoza and the History of an Image (Princeton: Princeton University Press, 2012). 
By the nineteenth century, the supremacy of science had reached the point that the philosopher Henri Laplace was sufficiently comfortable to respond to Napoleon's inquiry as to why he had not mentioned God in a discourse on the planetary orbits by saying, "Sire, I have no need for that hypothesis!" (Bartlett 1992, 351). Rejecting a requirement for a first cause permits pantheism to merge with atheism, as it had for Laplace.

For the eighteenth-century deists, God continued to serve a role as demiurge, but one who subsequently retired from creation, allowing it to function via the natural laws with which it had been imbued. This position countered the nominalist stance of the medieval scholastics who believed that God could, if he so wished, suspend the rules of nature at any point, as he had when the sun stood still for Joshua while conquering Jericho (Funkenstein 1986). Deists, including Thomas Jefferson and Benjamin Franklin, played an important role in the founding of the United States, so that the credo "In God We Trust" is perhaps more an affirmation of natural law than of Divine Providence. This post-Enlightenment idea had already been prefigured by the story of the Oven of Akhnai in Baba Metzia 59b, in which the rabbis argue that the Law, once given to man, was no longer "in the heavens," but must be decided by a majority of men without divine interference.

The new European zeitgeist in which individuals were free to express anti-clerical and even atheistic beliefs with impunity was transported in the early nineteenth century by Napoleon to Eastern Europe, and eventually reached the traditional Jewish enclaves of the Polish Pale. According to the historian Ada Rapoport-Albert, Hasidism, a movement that sought to reform Rabbinic Judaism, also desired to counter the effects of the Jewish Enlightenment or Haskalah (Rapoport-Albert 1996). The founder of Chabad Hasidism, R. Schneur Zalman of Lyadi, in spite of repeated imprisonment by the anti-Semitic Czarist government, feared that the new Napoleonic freedoms posed a far greater threat to Judaism's survival than Russian persecution.

Science, the handmaiden of the Enlightenment, began to encroach on the healing practices of Judaism. Ritualized prayer healing and 
amulets written by traditional Jewish healers, or B'aalei Ha Shem, increasingly took a back seat to modern medicine (Rosman 1996). But whereas medical science was rooted in the rigors of anatomy and physiology, the therapeutic approach to disorders of the mind still has not achieved the status of a physical science. Secular psychotherapies adopted religious ideas and rituals but disguised them as science. Freud's psychoanalysis attempted to fill the gap between science and religion but in so doing never achieved the rigor of the former or the depth of therapeutic feeling that may accompany the latter. It is from this perspective, (i.e. of psychoanalysis as a liminal endeavor), that it must rightly be examined.

\section{THE EMERGENCE OF PSYCHOLOGY}

As Jung notes, what were considered metaphysical disorders of the soul have, in a secular world, been reconceived as "mental illnesses." In antiquity, depression was generally attributed to sin, as in the case of King Saul's melancholia in 1 Samuel, and, until recently, psychoses were viewed as the result of demonic possession, a prime biblical example being Jesus' exorcisms of the demoniacs.

Following the witch craze that extended for several centuries and cost the lives of thousands in Europe and the American colonies-most of them women-scientific rationalism increasingly rejected the notion of demonic possession and instead postulated non-metaphysical biological causes of severe mental illness (Kradin 2012). Freud wrote in "A Neurosis of Demoniacal Possession in the Seventeenth Century" that:

What in those days were thought to be evil spirits to us are base and evil wishes, the derivatives of impulses that have been rejected and repressed. In one respect only do we not subscribe to the explanation of these phenomena current in medieval times; we have abandoned the projection of these into the outer world, attributing their origin instead to the inner life of the patient in whom they manifest themselves. (Standard Edition 1923, 72) 
In the late nineteenth century, the majority of patients seen in medical practice suffered from psychosomatic disorders, which were theoretically attributed to inherited vulnerabilities of the nervous system that were incurable (Shorter 1993). In part due to the clinical experiments of Martin Charcot, a French neurologist at the fin de siecle, it became apparent that the symptoms of hysteria, the most common nervous disorder in the nineteenth century, were in fact both reproducible and curable by "suggestion," suggesting that it was in fact a mental disorder.

Early psychoanalytical treatment was, like hypnosis, aimed at the relief of symptoms. This was true for Anna O. in Breuer and Freud's 1895 "Case of Hysteria," in which the "talking cure" was first reported, although the technique was, in fact, discovered by the patient. ${ }^{14}$ But Freud soon found that symptomatic cures rarely restore patients to health, as new symptoms invariably emerged with time. For this reason, psychoanalysis began to focus less on achieving symptom relief and more on the root of the problem, which was judged to be the need to transform character, although the latter approach is invariably lengthy and carries no guarantee of success (Eysenck 1994). Freud viewed his new ideas on neuroses as scientific. But as will be seen, they were instead deeply rooted in his Jewish milieu.

14. Anna O. was later revealed to be Bertha Pappenheim who went on to have her own illustrious career as a founder of the social work movement. 